\title{
The Historic Turn in Organization Theory. An Epistemological Enquiry
}

\author{
Enrico Beltramini
}

Notre Dame de Namur University

\begin{abstract}
This paper explores the power history holds for advancing organization studies and suggests that the historic turn in organization theory can 1) result in a new space for the application of organizational analysis; 2) work as an hermeneutical framework in a more self-conscious attempt to locate organization studies within their own histories; or 3) transform organization studies into 'new historicism, ' a literary genre. The paper investigates the intellectual roots of history as a discipline, and confirm the discipline as a stubborn bastion of empiricism/positivism, although exhibiting an increasing loss of appetite for naturalism. The paper also surveys historians' attempts to maintain a privileged third ground between natural science and literature, a tactic that resembles organization scholarship, and details the growing fascination with current reconceptualizations of the theory of history that lead to the notion of history as a form of narrative.
\end{abstract}

Keywords: historic turn - organization-epistemology - pluralistic character-theories of history

\section{INTRODUCTION}

While there is increasing consent on a clearly identifiable historic turn in relation to organization, questions emerge from historiography about the theory and methods of history as a discipline (i.e., Zald 1993 and 1996, Kieser 1994, Üsdiken and Kieser 2004, Ferguson 1997, Bucheli and Wadhwani 2014). Although most scholars agree that a 'historic turn' in organization theory marks the transition from a critical conception to a hermeneutical conception of knowledge, the extent of this transition is questionable (Clark and Rowlinson 2004, Jacques 2006). While history emphasizes concreteness and practical development, stresses sociality, and recognizes the immanent intelligibility of the human past, the historic turn in organization theory can 1) function as a supplement to the ongoing narrative turn in organization studies,2) assert the ontological identity of history and reality (history as reality, the reality is historical), or 3) end in a reverse turn, in which history is exposed to organizational analysis rather than organization is exposed to historical enquiry. The historic redirection in organization theory can clearly assume multiple configurations.

This article covers all three options: 1) the reverse turn as an extension of organizational analysis to history; 2) the historical consciousness as an excursion of historians into organizational territories; and 3) an integral reshaping of the whole discipline in terms of non- scientific discourse.

This paper addresses the 'meta-historical question,' namely the topic of the disciplinary nature and status of history in terms of methods and styles, relationship with science and literature, and applications and public uses; the study then advances three claims. First, despite the late-modern or postmodern pluralism that led to the hypothesis that the historic turn in organization theory can assume many, perhaps infinite configurations, that organizational scholars should be aware that the most valuable aspect is that the possible configurations are, in fact, only three in number. Second, in assessing the three configurations of the historic turn in their discipline, scholars should study the historical roots of these configurations to benefit from the study of aspects of intellectual history, which are present in the historical work of scholars from Henri Berr and Benedetto Croce to Carl Hampel and Hayden White. Third, organizational scholars should recognize the emergence of the notion of history as a post-metaphysical enterprise, a history whose explanatory framework for historical facts is not supra-historical, to better grasp the wider implications of these configurations on their discipline. This approach has also caused the consequent transformation of historical discourse into a form of literary genre. Discussion of some theories of history will precede a final assessment of the historical turn in organization theory. 


\section{THEORIES OF HISTORY}

Organizational scholars are aware that history is currently in a phase of re-conceptualization. Among historians, the claim of scientific, objectivist thinking to irrefutable truth, independent of subjective and personal experience as claimed in the Enlightenment (in terms similar to natural science) is only held by conservative historians like Gertrude Himmelfarb, John Vincent, David Harlan and Keith Windschuttle. Mainstream historians such as Peter Novick and Richard Evans are reworking the notion of objectivity while maintaining that history is a scientific, rather than a humanistic, discipline. While Novick (1988) demonstrates how the idea of objectivity has been modified and defended over the past century, Evans (1997) not only defends historians from the criticism that facts cannot exist outside of language, but shows how the discipline is adapting to this assault on its empiricalrationalist base. Evans denies that all of history is interpretation and that no one interpretation is better than any other, although he concedes that a historian can eventually import prejudices into an object of study. He supports the scientific method; and believes that careful and honest sifting of the historical record will prove some interpretations to be better grounded in the historical record than others. On the other hand, Evans is excited to explore some of the possibilities for history that have been opened up by the notion of extended historical knowledge, a knowledge that goes beyond the perimeter of natural science. Ultimately, Evans proposes a more modest claim for historical knowledge: rather than renouncing the idea of an autonomous reality of the past, which can be known only imperfectly, mainstream historians work to incorporate the new approaches of methodology and epistemology that Karl Popper and Thomas Kuhn have described as models of scientific enquiry and analytical philosophies of history. The overarching Kantian thesis is that historians are finite creatures and that history must reflect this fact, although the existence of the past is not questioned and neither is the validity of historical knowledge in the search for the truth.

The amendments to the classic empirical-rationalist approach to history also resonate for historians at the crossroads of history and the social sciences, such as William H. Sewell Jr., who maintain that history as a discipline possesses its own scientific methods and standards of intellectual inquiry. These historians' basic assumption is that despite the impression of fragmentation recently created by postmodernism, history is a coherent discipline which still bears the imprint of its nineteenth-century scientific origins. These scholars have expanded their work to create a theory of history that adopts internal methods and standards for the historical profession as a means of expressing facts, as opposed to the verification epistemology of modern rational objectivism. These intellectuals defend classical methods for proving the validity of facts, upholding the notion that a chain of facts can be reasonably deduced from the proper chronological arrangement of events. Despite of the frequent insistence by scientists that history is not a science in natural science terms, historians themselves have committed to strengthening the concept of history as a scientific discipline. Historians create the distinction from the classical notion of science, as well as literature, avoiding traditional patterns of writing and adopting quantitative methods and concepts from the systematic social sciences. Hayden White famously described this option as a middle ground between science and art that history has enjoyed since the mid-nineteenth century.

Historians [...] claim occupancy of an epistemologically neutral middle ground that supposedly exists between art and science. Thus, historians sometimes argue that it is only in history that art and science meet in harmonious synthesis. According to this view, the historian not only mediates between past and present; he also has the special task of joining together two modes of comprehending the world that would normally be unalterably separated (White 1966, 112)

However, not all historians are at ease with a more or less aggressive use of the scientific premise, as some seem to have lost confidence in the notion that knowledge is founded upon universal principles and empirical fact. Hayden White (1973), Frank Ankersmit (1995), Dominick LaCapra (1985), Keith Jenkins (1992), and Joan Scott (1988) assume that history is either dead or merely grouped alongside literature. In the first case, the past is relegated to intellectual oblivion, history is no longer incorporated into every branch of education and public life, and the historical knowledge is valued less and less. Historians prove irrelevant in the present day, providing nothing more than an academic method caused the collapse of the belief in the importance of history to this present time. In the second case, history's claims to objective knowledge are critiqued by post-foundationalists who argue that facts cannot exist outside of language, while history as much as literature is saturated with fictional characters. The basic criticism is that history has been practiced in a way that presupposes the past actually happened and that historians can reach some tenable conclusions about what the past 
was if scrupulous and self-critical in the historical investigation. Moving beyond the traditional focus of historiography, historians who embrace a more humanistic approach ultimately claim the identity of history as literature. In that view, the 'linguistic turn' in history can help to relieve historians of the narrowness of theoretical orthodoxy (i.e., Sewell 2005, McDonald 1996, Mahoney 2003).

In summary, the discipline has settled on three options, according to different levels of trust in historical truth: 1) remaining firm in the belief that the historian can recapture the historical past with certain levels of objectivity, 2) embarking on an attempt to maintain a privileged middle ground between natural science and art, and 3) demonstrating that the work of history is a form of rhetoric (Iggers 1997). While a brief history of the twentieth-century historiography is essential, it is worth anticipating that this clear preference for a middle ground between the extremes of the critical historicism of the Enlightenment and postmodern relativism, practically leads to the choice to incorporate many criticisms and methods of the postmodernist theorists, without abandoning the pursuit of verity. Truth may still be elusive, but it is still an attainable outcome.

In 1932, when Henri Berr and Lucien Febvre (1933, 7:761) submitted their entry 'History' to the Encyclopedia of the Social Sciences, the discipline was firmly situated in the middle ground between natural science and art. History was a science of its own, assuming a more critical or speculative form according to its distance from natural science, while philosophy of history was articulated as a natural counterpart to philosophy of science and aesthetics. The division between critical and speculative forms of history mirrored a principled division between scientific history and philosophical history $a$ la Hegel and Marx (Danto 1965). The division of history into critical and speculative also reflected different historical forces, with social history (or historical sociology) poised as a subdivision of history compatible with natural science because it worked with models and quantities, and Marxism, which was more concerned with conventional forms of narrative history and aimed to aligning history with the collective consciousness. The French Annales school of historians occupied a unique place at the confluence of critical and speculative theories of history.

Critical forms of history shared with logical positivism the enthusiasm for quantification and behavioral theories and assumed a great deal of generalization, explanation, and causal reasoning (Klein 2011, 55). Logical positivism has made it easier for historians to avoid historicizing their own preferred practice and to learn historical methodology through practice rather than speculative training. Klein, an intellectual historian, points out that logical positivistic historians learned research methods as if they were the result of timeless revelation. Historians practiced history with no need of more than a rudimental understanding of theory because logical positivism freed historians from the inconvenience of historicizing their work. The assimilation of history into science invited a conversation about history in the context of the philosophy of science, while epistemology focused the attention of theorists on historical knowledge, according to the principles suggested by logical empiricists such as Carl Hampel assuming that historians should meet the same logical criteria as scientists, subsuming specific events under general laws (Klein 2011, 33 and 36-7). Economic history provides a case in point: since the 1970s, this scholarly discipline has embraced an aggressive use of economic models and statistics, identifying economic history with logical-mathematical analysis.

Critical forms of history survive as the last remaining refuge for all of the historians who maintain that history possesses 'material criteria of truth' and that, within limits, the past can be known and reconstructed (Bahners 1992, 313). While historians are becoming increasingly aware of the role of language in the historical discourse, and recognize that a fictional element is required in historical narrative to place empirically validated facts in a coherent story, not all are ready to accept the nonreferential character of the historical text; that is, there is no such thing as a past that is reflected in the historian's writing. Thus, while scholars acknowledge the literary nature of historical texts and the fictional parts historical texts inevitably contain, these scholars claim that these inventions are not arbitrary creations but actually reflect some of the logic of scientific inquiry.

Speculative forms of history share with structuralism and postmodernism the hostility toward universal history and its metanarratives and metaphysics, and, in addition, acquired a whole catalog of associations such as language, narrative, and culture. Structuralism and postmodernism offered at least three new modes of historical discourse and related vocabulary: differently historical (local, postcolonial, anthropological, etc.), non-historical (deconstructionism), and anti-historical (history as literature and art). Narrative-linguistic approaches share an increasing dissatisfaction with speculative forms of history with other social science modes, that is, the notion of 'coherent scientific 


\section{Enrico Beltramini}

explanation' of past events (Stone 1979, 3-24), and the highly scientific modes of historical discourse. The twentieth-century attempt to build a profession on either scientific methods or universal social history failed, leaving historians no choice but to recognize the literary character of the historical enterprise. First, 'historical narratives' and then 'history as literature' were explored, in which the former reflects an increasing awareness of the fact that history is always written as a narrative, and that historians should emphasize the linguistic tools with which they construct their accounts. The latter is the more radical view that history is a literary style, which has 'more in common with their counterparts in literature than [it has] with those in the sciences' (White 1978, 82).

Hayden White, among the most influential American intellectual historians of the past half century, aligns with a counter-tradition that delights in undermining the magisterial image of the historians who pretend to play the same major role in intellectual life as that enjoyed by nineteenth-century European historians, without recognizing that the time in which historical consciousness was the central pillar and essential framework for Western civilization is over. The new conceptions of science and the evolution of art had changed the fundamental assumption that history was a privileged third area between science and art, undermining the authority of the discipline and leaving it with no place to go (While 1966). White argues that trying to trace a line from the past to the present is futile and that acquiescence to the oblivion of history was better than attempting to reach a temporal dimension and an organic connection with the past. He suggests historians abandon certainty of the past as an historical ideal and try to appreciate the irreducible temporality of everything. White also advocates that scholars try to understand history as a contingent narrative readable without an assumption of truth behind the narrative. He aims to rescue historians from their truth-seeking constraints, as history is a construction of the historian living in the present, a reference to Croce's famous aphorism, 'every true history is contemporary history.' (Croce 1960, 12).

A post-foundation notion of history seeks a way to say something about history which will convey the idea of representation while promoting the autonomy of the meanings derived from past reality. Historians should champion a conception of historical inquiry that regards history as a genre of literature, while letting literature displace a kind of representation in no way related to reality or epistemological goals but rather tied to aesthetic aspirations. History as a discipline should be concerned with the way in which a new description of the past comes about and a wider expressive capacity is produced. The retreat from scientific and social history changes the status of historical inquiry, forcing historians to live in the present, conditioned by the categories of thought in which they operate when they pursue historical research. Therefore, attempts to recapture the historical past and reflect its reality in objective representations, in the conviction that rational methods lead to truthful insights into the past, are deceptive. In fact, there is no direct connection between the historical enterprise and the reality of the past, as historians inevitably construct their historical narratives rather than referring to history itself, and the only obstacle to the complete identification of history with fiction rests on a historian's integrity.

\section{Historical TURN IN ORganization THEORY}

Where a scholar of organization theory stands on the significance of the historic turn depends upon how he or she views history. According to the tripartite notion of history as part of natural science, social science, or literature, and in spite of this rich variety of methodological shifts of interest, most organization scholars would agree that history is founded on one of the following three viewpoints:

i. The empirical-rational model, which claims that historians can reach the complete truth about the past and its supra-historical truths (supra-historical truths revealing themselves in history). This model prioritizes objectivity and truth-seeking methodology, and sees history as an evidence-based enterprise, in which historians rely upon evidence in attempts to represent the reality of the past. The status of historical knowledge is similar to scientific knowledge, as the discipline processes thoroughly historical ideas and events through a scientific methodology so that history can build a mirror of the past;

ii. The social-historical model, in which history takes social form. This model denies supra-historical truths and locates the meaning of past ideas and events so firmly in their context that history, rather than natural science, becomes the arbiter of historical truths -- truths relative to particular times and places -- while recognizing the reality of the past itself. Accordingly, historic narratives maintain a scrupulous regard for the historicity of the past, and tries to accurately reconstruct it as it 'actually was,' to coin Ranke's famous phrase; 
iii. The literary-narrative model, which denies supra-historical as well as historical truths, since the historical enterprise exists only in the present and is impractical for reaching any objective truth about the past. This model claims that history is not a total or partial representation of the past, but rather a narrative about the past constructed by the historian in the present; like any text, historical narrative is subject to the manipulation of the 'historical imagination.' Accordingly, the historical enterprise appears to be more literary than historical, since there is no distinction between history and literature (i.e., Iggers 1997, Lorenz 1998 and 2011, Munslow 2003, Green 1999).

Each of these viewpoints of history generates a distinct significance of the historic turn for organization theory scholars. These viewpoints can be categorized into one of three scholarly epistemological strategies: 1) history becomes a new application of an extended notion of reason in organizational science; 2) history represents a unifying principle or an hermeneutical tool of an epistemological middle ground between organization science and studies; and 3) history is the manifestation of creative imagination that identifies history with literature.

An example of the first strategy is economic history, which is now understood as a scientific rather than humanistic discipline. The modern community of economic historians unanimously emphasizes purely mathematical analyses of economic events, recognizing that economic history investigates economic phenomena with tools similar to those of economics. Accordingly, economics has entered a phase of aggression toward the other social sciences, an offensive based on the premise that economics can help explain noneconomic phenomena better than the social sciences that may focus on doing just that. Every aspect of human behavior should be considered 'economic,' that is, selfinterested and wealth-maximizing. Once embraced in organization theory, this epistemological strategy resolves in a reverse turn, in which history becomes a new application of an extended notion of scientific reason in organizational theory.

Organizational scholars might find the idea of history as an empirical-rational enterprise useful on the basis that the traditional meaning of science has run its course, and that it is a matter of going 'beyond' that meaning through an extended notion of pure rationality. Accordingly, an historic turn considers history as the new territory in which the logic of organization science can be extended to extra-scientific domains. An historical stance can exist within an enlarged concept of organization science on the condition and to the degree that the former respects the criteria of the latter; and is subordinated to it. Once incorporated in a scientific domain, history can work as an antidote to the tendency of some rationalists, who are so heavily influenced by logic as to neglect imagination. History is especially qualified to work as a partial concession to those who think it is crucial to convey a sense of the importance of 'the reason of the heart,' a form of rationality that crosses scientific boundaries (Pascal 1660, 50). ${ }^{1}$ In this epistemological perspective, the study of organizations should be modeled on post-positivism (Üsdiken and Kieser, 2004).

An alternative strategy for organization scholars is to determine history as social science useful toward maintaining their field of intellectual endeavor as an epistemologically neutral middle ground that exists between the scientific and 'spiritual' approaches-organization science and studies. Organization theory, as intellectual discourse, is not a settled body of principles; it is a heterogeneous discipline with numerous traditions, each based on a cluster of theories. For the sake of simplicity, it can be said that for fifty years, organization theory has been shaped by two major intellectual traditions. The first is 'sociological positivism' that applies models and methods from the natural sciences to social affairs. The second is 'German idealism,' which sees reality in the 'spirit' or 'idea' and rejects the scientific methodology as a means to understanding behavior (Burrell and Morgan 1979). Each tradition suggests that organization theory can be expressed either in the form of discursive reason (or in the form of social conscience) and imagination. The former expresses a style of reasoning dependent on a notion of human reason as natural reason, which prides itself on being above history. Accordingly, organization is a science driven by unchanging concepts that set up perennial truths. Naturalists aim to relocate human reason in nature, liberating organization theory

\footnotetext{
${ }^{1}$ According to Blaise Pascal, a seventeenth-century mathematician, scientist, inventor and Christian apologist, the heart is "the 'intuitive' mind." In other words, there are times that we know something is true from the heart, as knowledge is not synonymous of logical reasoning. Accordingly, knowledge of heart and knowledge of reason might be arrived at truth in different ways, but they are both valid. The best known quotation of Pascal on the subject: "The heart has its reasons which reason does not know." Quote from: Blaise Pascal. Pensées (1660). Trans. W. F. Trotter. New York: Collier \& Son, 1910, 50.
} 
from all traces of history while grounding it in foundational epistemology, presenting organization theory as something consistent with scientific reason. The latter typifies a more contingent approach, creating room in the discipline not only for science but also for an historical notion of human reason. For partisans of historicized reason, the theories of organization studies are understood historically and situated in time, embedded in a social and linguistic community; and dependent for their ideas and beliefs on a process of cultural character (McCarthy, xv). Accordingly, organization studies are an historical enterprise that depends upon intuitive methods and in which data are open to 'free' manipulation (Hollis 1994). Two different ways of thinking about organization theory are at stake: an organization 'science,' based on logic and the results of the natural and exact sciences, and organization 'studies,' which considers organization theory based on history. Understood in this sense, the relationship between organization science and organization studies is the same as the one between science and the humanities (Rickards and De Cock 1999).

This tendency to consider history as part of the social sciences argues for the sheer diversity of historical research and methods of investigation, as opposed to natural science, although it does not classify history as a branch of literature. Organizational scholarship sometimes maintains the two distinct intellectual traditions of science and history as two alternative, competing notions of human reason. A problem with this strategy is the tendency of scholars to bifurcate science and conscience -between 'everything is nature' or 'everything is history' -- into completely separate disciplines and then to present organization science as something consistent with scientific reason, and to position organization studies as an historical enterprise that depends on intuitive methods. Another problem is the status of scientific and historical truths. While the sciences are experimental, history is more a 'theory' rather than something factual. Accordingly, organization science claims to be a privileged source of truth. Organizational scholarship sometimes proposes a sort of blending of the two distinct major intellectual traditions of science and history on the basis of an imagined, pre-existing complementary between the two, to the point that in the same discipline there coexists the atemporal objectivity of organization science and the sense that organization studies are a process, which therefore have a history. According to this view, organization scholars not only pursue both organization science and organization studies, but also mediate between the two and take on the special task of merging two modes of comprehending organizations that would normally be unalterably separated.

If history is primarily concerned with the socioeconomic substructure of civilization and the interaction of cultural, social, and economic factors, organization scholars maintain their claim to be 'scientific' without being naturalized, assuming a sort of realistic stance. In this context, an historic turn re-establishes organization theory in its synthetic totality as a comprehensive structure of meaning, healing the intellectual wounds of methodological pluralism, and locating organization studies in their own histories. History can operate as a unifying principle, outside the hegemony of natural science and without being troubled by the apparently relativistic implications of opposing it, protecting the intrinsic pluralism of organization theory, and counter its ongoing fragmentation that is fuelled by scholarship's eclecticism (Zald 1991). Organization scholars can import historical consciousness into their discipline, adopt the sense of history as a theoretical framework, and embed it into the fabric of their intellectual life.

Finally, organization scholars might find history as literature to be a useful perspective to use to sketch the contours of a more radically historicist view of the world and recognize that they 'do' organization scholarship through a sort of narrative method. This ultimately depends on expressions, as it is the narrative structure of the story that enables evidence to acquire its non-fictional status. In this context, the historic turn represents the severance of organization theory from the notion of (objective) representation, while the goal is to liberate organization theory from science and purge it of metaphysical elements to the point that organization theory is synonymous with rhetoric. The expression is not considered a secondary instrument or a means with which already formed knowledge could be expressed publicly, because when historians give shape to their knowledge of the past, they do not limit themselves to putting knowledge into a uniform, transparent bag. Actually, expression is that shape, because 'we can think only that which we can express in words' (Janik and Toulmin 1971, 121). It is not the expression that depends on the knowledge of the past, but the knowledge of the past that depends on its expression. Organization studies do not exist as a means of representation but are a form of expression; accordingly, organization scholarship is a non-privileged, non-representational narrative about the organizations. 
An historic turn in organization theory from such a strong anti-historical posture, reinventing history as art, might force scholars to stop seeking particular truths or past realities to describe. This would enable them to instead connect to current social and political questions, participate in the social conversation, and ultimately affect the public sphere in a positive way. In addition, building on Thomas Kuhn's concept of paradigm, history as a literary genre explores the hidden assumptions of social and organizational theory, with the underlying thesis that all theories of organization are based on implicit images or metaphors that stretch the imagination in ways that can result in powerful insights, but do distortion. An historic turn can ultimately expand the portfolio of metaphors and narrative styles, while investigating new meanings and exploring new literary territories.

In the 1980s, in response to a crisis in the social sciences, advocates of narrative proposed a new paradigm for studying organizations (Riessman 1993). Drawing on the work of thinkers from a variety of philosophical schools, it became fashionable to suggest that organizational problems were all problems of language, and that if organization scholars paid close attention to stories and narratives, and devised a perfect metaphor free of the inconsistencies of the mechanistic paradigm, then organizational problems would disappear. Thus, while narrative is a noble attempt to reinvent the structures of knowledge with which scholars study organization, a historical turn in organization theory can prove that problems of the discipline arise not from theoretical inconsistencies inherent in organizational studies, but from the inadequacy of the notion of historicism embraced as a literary genre for addressing emerging topics. To reiterate, if narrative is not a new research method but rather a fundamental rethinking of what scholars consider knowledge, the problems arose not because organization theory is unable to articulate a universal set of principles, but rather because of the inability to adopt an appropriate historical style of writing.

While the first and the second epistemological perspectives do not seem to offer a radical alternative to the current state of organization theory, the third one does. In fact, those organization scholars who see history as an extension of logic and pursue an assimilation project firmly rooted in the tradition of instrumentation of history are using ammunition that has been in use for decades. In this capacity, it is clear that history is already at work in the discipline. The second perspective continues a tradition in organization theory in which scholars claim that their field relates to social affairs and is a kind of middle ground that provides an indication of the difficulty organization scholars have in grasping the center of gravity of their discipline. An historic turn in organization theory might resolve in a new common ground - or rather a kind of armistice between the two intellectual traditions of sociological positivism and German idealism as they relate to assimilation or complementarity. The third perspective, with its view of a non-metaphysical genre of literature, makes clear that a deeper set of questions about epistemological priorities are at stake in an historic turn in organization theory.

\section{Conclusion}

This article is an interdisciplinary work investigating the historic turn in organization theory as one of the most striking intellectual developments in management studies. It gives a sense both of what these various meanings of the turn to history have in common and what sets them apart. It goes beyond a mere inventory of these meanings to ask how and to what extent history can make a difference in organization theory; how the practice of history is affected by organization science, what is left of both social science after the historic turn, and the perspectives of 'new historicism' in organization theory.

In addressing this turn toward history, scholars in organization theory should be aware of the pluralistic reality of the historic realignment and deepen their understanding of the effects of a more central role of history in their discipline. In other words, efforts to characterize the historic turn as simply the idea that organization theory is embracing historical approaches, while true in a general sense, only partially represents the enterprise; this actually makes it difficult for organizational thinkers to penetrate the core of that approach. At the very least, scholars need to recognize the key theses of this turn toward historical methods and the frameworks at work, familiarize themselves with the available options, and position themselves in regard to these options, which in turn, determines their attitude toward the role of history in their discipline (Lorenz 2011; Rowlinson and Hassard 2011).

While this article deals with the use of history to organizational theorists, organization scholars should be aware that historians are slowly leaving behind their earlier historical images of transcendent realities or objective representations of the past to become involved in investigation of secular 
contingencies. Accordingly, the view of an historical turn in organization theory that significantly affects the understanding of the issues and the direction of organization theory suggests that organization scholars approach history, or the radical immanence of the spirit, in Croce's terms, with a clear understanding of the epistemological goals of their discipline and the specific concerns of their day, and ultimately with caution (Roberts 1995, 28).

\section{REFERENCES}

Ankersmit, F.R. 1995. A New Philosophy of History. Chicago: University of Chicago Press.

Bahners, P. 1992. 'Die Ordnung der Geschichte: Uber Hayden White,' Merkur, 46 (1992) Heft 6 (1992), 313.

Berr H. \& and Febvre, L. 1932. "History," in E. R. A. Seligman (Ed.), Encyclopedia of the Social Sciences, Vol. 7: 357-368. New York: Macmillan.

Bucheli Marcelo \& Wadhwani R. Daniel (Eds.). 2014. Organizations in Time: History, Theory, Methods. Oxford: Oxford University Press.

Burrell, G., \& Morgan, G. 1979. Sociological Paradigms and Organisational Analysis. Aldershot: Gower.

Clark, P., and M. Rowlinson. 2004. 'Treatment of History in Organisation Studies: Towards an “Historic Turn”?' Business History, 46(3): 331-52.

Croce, B. 1960. History: Its Theory and Practice, Douglas Ainslie (tr.). New York: Russell and Russell.

Danto, A. C. 1965. The Analytical Philosophy of History. New York: Colombia University Press.

Evans, R. 1997. In Defense of History. London: Granta.

Ferguson, N. 1997. 'Virtual History: Towards a "Chaotic" Theory of the Past.' In N. Ferguson (Ed.), Virtual History: Alternatives and Counterfactuals: 1-90. London: Papermac.

Green, A. 1999. The Houses of History: A Critical Reader in Twentieth-Century History and Theory. New York: New York University Press.

Hollis, M. 1994. The Philosophy of Social Science. Cambridge: Cambridge University Press.

Iggers, G. G. 1997. Historiography in the Twentieth Century: From Scientific Objectivity to the Postmodern Challenge. Middletown, CT: Wesleyan University Press.

Jacques, R. 1996. Manufacturing the Employee: Management Knowledge from the $19^{\text {th }}$ to the $21^{\text {st }}$ Centuries. London: SAGE.

Jacques, R. S. 2006. 'History, Historiography and Organization Studies: The Challenge and the Potential.' Management \& Organizational History, 1(1): 31-49.

Janik, A. \& Toulmin, S. 1973. Wittgenstein's Vienna. New York: Simon and Schuster.

Jenkins, K. 1997. The Postmodern History Reader. London: Routledge.

Kieser, A. 1994. 'Crossroads - Why Organization Theory Needs Historical Analysis - And How This Should be Performed.' Organization Science, 5(4): 608-620.

Klein, K. L. 2011. From History to Theory. Berkeley: University of California Press.

LaCapra, D. 1985. 'Rhetoric and History.' In Dominick LaCapra (Ed.), History and Criticism (pp. 1544). Ithaca: Cornell University Press.

Lorenz, C. 1998. 'Can Histories Be True? Narrativism, Positivism, and the "Metaphorical Turn".' History and Theory, 37(3): 309-29.

Lorenz, C. 2011. 'History and Theory.' In A. Schneider and D. Woolf (Eds.), The Oxford History of Historical Writing (pp. 13-35). Oxford: Oxford University Press.

Mahoney, J. 2003. Comparative Historical Analysis in the Social Sciences. Cambridge: Cambridge University Press.

McDonald, T. (Ed.) 1996. The Historic Turn in the Human Sciences. Ann Arbor, MI: University of Michigan Press.

McCarthy, M.H. 1990. The Crisis of Philosophy: Emerson in the Twenty-first Century. Albany NY: SUNY Press.

Munslow, A. 2003. The New History. Harlow: Pearson Education. 
Novick, P. 1988. That Noble Dream: The 'Objectivity Question' and the American Historical Profession. Cambridge: Cambridge University Press.

Pascal, B. Pensées (1660). Trans. W. F. Trotter. New York: Collier \& Son, 1910.

Richards, T., \& De Cock, C. 1999. Sociological Paradigms and Organizational Creativity. In A. Montuori \& R. Purser (Eds.), Social creativity, vol. 2: 235-256. Cresskill, NJ: Hampton Press.

Riessman, C.K. 1993. Narrative Analysis. Newbury Park, CA: Sage.

Roberts, D. D. 1995. 'Croce in America: Influence, Misunderstanding, and Neglect.' Humanitas, 7(2): 3-34.

Rowlinson, M., \& Hassard, J. 2011. Historical Methods in Management and Organization Studies. Gothenburg: European Group for Organizational Studies.

Sewell, W. H., Jr. 2005. Logics of History: Social Theory and Social Transformation. Chicago: University Of Chicago Press.

Scott, J. 1988. 'Introduction.' In Joan Scott (Ed.), Gender and the Politics of History (pp. 1-11). New York: Columbia University Press.

Stone, L. 1979. The Revival of Narrative: Reflection on a New Old History. Past and Present, 85 (Nov): 3-24.

Üsdiken, B., \& Kieser, A. 2004. Introduction: History in Organisation Studies. Business History, 46(3): 321-330.

White, H. 1966. The Burden of History. History and Theory, 5(2): 111-134.

White, H. 1973. Metahistory: the Historical Imagination in Nineteenth-Century. Baltimore: The Johns Hopkins University Press.

White, H. 1978. 'Historical Texts as Literary Artifact. In Tropes of Discourse. Essays in Cultural Criticism (pp. xx-xx) Baltimore: The Johns Hopkins University Press.

Zald, M. N. 1991. Sociology as a Discipline: Quasi-Science and Quasi-Humanities. American Sociologist, 22(3-4): 165-187.

Zald, M. N. 1993. Organization Studies as a Scientific and Humanistic Enterprise - Toward a Reconceptualization of the Foundations of the Field. Organization Science, 4(4): 513-528.

Zald, M. N. 1996. More Fragmentation? Unfinished Business in Linking the Social Sciences and the Humanities. Administrative Science Quarterly, 41(2): 251-261. 